\title{
IMPLEMENTASI METODE ASOSIASI APRIORI UNTUK MENGETAHUI POLA BELI KONSUMEN DAN REKOMENDASI PENEMPATAN PRODUK PADA SWALAYAN XYZ
}

\author{
Muchamad Taufiq Anwar ${ }^{1}$, Hindriyanto Dwi Purnomo ${ }^{2}$, Mega Novita $^{3}$, Clara Hetty Primasari ${ }^{4}$ \\ ${ }^{1}$ Program Studi Teknik Informatika, Fakultas Teknologi Informasi, Universitas Stikubank \\ ${ }^{2}$ Program Studi Sistem Informasi, Fakultas Teknologi Informasi, Universitas Kristen Satya Wacana \\ ${ }^{3}$ Program Studi Informatika, Fakultas Teknik dan Informatika, Universitas PGRI Semarang \\ ${ }^{4}$ Program Studi Sistem Informasi, Fakultas Teknologi Industri, Universitas Atma Jaya Yogyakarta \\ e-mail: ${ }^{1}$ taufiq@edu.unisbank.ac.id, ${ }^{2}$ hindriyanto.purnomo@ staff.uksw.edu, ${ }^{3}$ novita@upgris.ac.id, \\ ${ }^{4}$ clara.hetty@uajy.ac.id
}

\begin{abstract}
Abstrak
Bisnis retail merupakan bisnis yang keberhasilannya sangat dipengaruhi oleh kemampuan untuk memahami perilaku konsumen dan kesigapan respons dari pemiliknya. Memahami konsumen dapat dilakukan dengan mempelajari data historis dari transaksi konsumen. Metode association rule-mining dalam Machine Learning dapat kita manfaatkan untuk menemukan tren pola perilaku beli konsumen yang menunjukkan keterkaitan antar produk / kategori produk. Penelitian ini bertujuan untuk menemukan tren asosiasi kategori produk serta memberikan rekomendasi penempatan produk (product placement layouting) dengan memaksimalkan exposure pembeli terhadap produk-produk yang terkait saat berbelanja suatu barang dengan harapan akan terjadi peningkatan penjualan. Sebanyak 12.760 data transaksi digunakan untuk menemukan tren asosiasi antar barang yang beli konsumen. Berdasarkan tren asosiasi ini, dibuatlah rekomendasi layout peletakan produk untuk memaksimalkan exposure barang terkait saat konsumen berbelanja suatu barang sehingga diharapkan akan terjadi peningkatan penjualan.
\end{abstract}

Kata Kunci: market basket analysis, apriori association analysis, retail layout

\section{PENDAHULUAN}

Bisnis retail merupakan bisnis dengan tingkat kompetisi yang sangat tinggi. Keberhasilan bisnis retail sangat dipengaruhi oleh kemampuan untuk memahami perilaku konsumen dan kesigapan respons dari pemilik usaha retail. Bisnis retail harus berfokus kepada konsumennya karena ia merupakan pemain penting di ujung rantai distribusi[1]. Memahami konsumen dapat dilakukan dengan mempelajari data historis dari transaksi konsumen[2]. Metode association rule-mining dalam Machine Learning memungkinkan kita untuk dapat melihat tren pola perilaku beli konsumen yang menunjukkan keterkaitan antar kategori produk maupun antar produk secara individual. Produk yang dipilih konsumen ketika berbelanja akan menunjukkan preferensi keterkaitan antara produk-produk. Dengan mengetahui tren asosiasi produk yang dibeli konsumen, pemilik retail dapat mendesain layout peletakan produk yang dapat membuat konsumen tergerak untuk berbelanja lebih banyak[2]. Penelitian ini bertujuan untuk mengetahui pola keterkaitan produk-produk di Swalayan XYZ berdasarkan data historis pembelian di swalayan tersebut. Berdasarkan pola keterkaitan tersebut akan diberikan rekomendasi penempatan produk untuk meningkatkan penjualan.

\section{TINJAUAN PUSTAKA}

\subsection{Market Basket Analysis}

Market Basket Analysis adalah metode analisis komposisi barang-barang yang dibeli konsumen dalam setiap pembelian yang dilakukan. Data mentah untuk market basket analysis biasanya berupa struk pembelian. Market basket analysis bertujuan untuk 
menemukan pola keterkaitan barang yang dibeli secara bersamaan[2]. Misalnya, seseorang yang membeli susu biasanya juga akan membeli roti. Aturan (rules) keterkaitan antar barang biasanya dinyatakan dalam format sebagai berikut:

$$
\text { IF }\{\text { susu }\} \text { THEN }\{\text { roti }\}
$$

Pemilik retail dapat memanfaatkan informasi ini dengan menempatkan barang-barang yang berkaitan saling berdekatan sehingga lebih mudah terlihat dan terjangkau oleh konsumen saat berbelanja. Cara penempatan ini dapat mempengaruhi perilaku beli konsumen dan meningkatkan penjualan untuk barang yang berkaitan [1].

\subsection{Association Rules}

Sebuah association rule adalah pernyataan implikasi dalam bentuk $\mathrm{X} \rightarrow \mathrm{Y}$, di mana $\mathrm{X}$ dan $\mathrm{Y}$ adalah dua item yang berbeda. Kekuatan association rules dapat diukur melalui besaran support dan confidence. Support menunjukkan seberapa sering aturan (rule) tersebut dapat diterapkan pada suatu set data, sedangkan confidence menunjukkan seberapa sering item Y muncul dalam transaksi yang melibatkan X[3]. Definisi formal dari support dan confidence ditunjukkan dengan persamaan (1) dan (2).

$$
\begin{aligned}
& \text { Support, } S(X \rightarrow Y)=\frac{\sigma(X \cup Y)}{N} \\
& \text { Confidence, } C(X \rightarrow Y)=\frac{\sigma(X \cup Y)}{\sigma(X)}
\end{aligned}
$$

\subsection{Metode Asosiasi Apriori}

Association analysis merupakan cabang Machine Learning yang berguna dalam menemukan keterkaitan (association rule) yang tersembunyi dalam sebuah dataset yang besar. Metode penentuan aturan asosiasi (association rule mining) pertama kali dikemukakan oleh Agrawal, et. al. pada tahun 1993[4]. Metode ini telah lama digunakan pada analisis data transaksi seperti Market Basket Analysis[3].

Dalam association analysis, prinsip apriori menyatakan bahwa: Jika suatu itemset (barang yang dibeli bersamaan) sering muncul (support-nya tinggi), maka semua subset-nya juga pasti akan sering muncul. Dalam menemukan association rule, metode asosiasi apriori akan membuang itemset yang tidak mencapai batas minimal support tertentu (support-based pruning). Metode apriori menemukan association rule dimulai dengan menghitung support untuk 1-itemset dan secara iteratif menambahkan satu item ke dalam itemset dan mengevaluasi support-nya[3]. Pseudocode Algoritma Apriori ditunjukkan pada Algoritma 1.

Kode Program 1. Pseudocode Algoritma Apriori

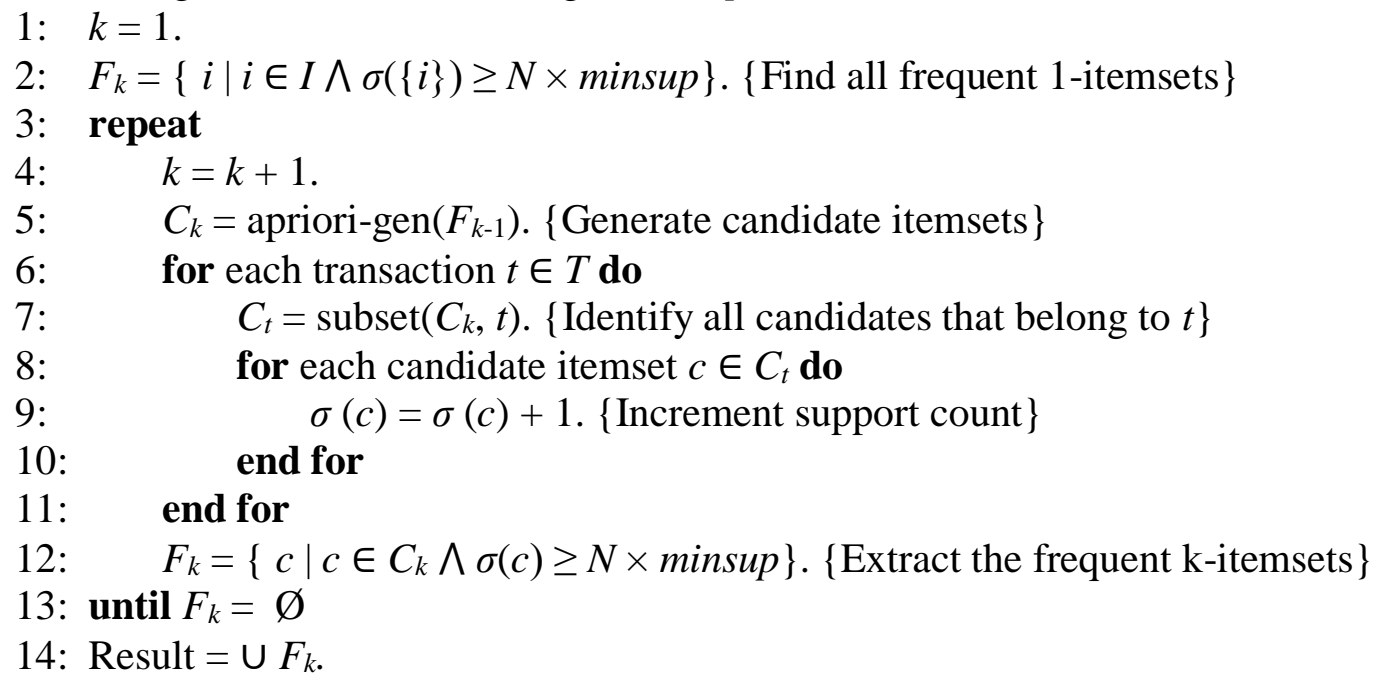


Dalam perkembangannya, metode asosiasi apriori telah mengalami modifikasi seperti yang baru-baru ini dilakukan oleh Yuan[5]. Beberapa perbaikan yang dilakukan yaitu: 1) penggunaan cara pemetaan basis data baru untuk menghindari pemindaian basis data yang berulang kali; 2) pemangkasan lebih lanjut pada frequent-itemset dan itemset kandidat untuk meningkatkan efisiensi penggabungan; 3) penggunaan strategi tumpang tindih (overlap) untuk menghitung support untuk mencapai efisiensi algoritma yang tinggi. Modifikasi yang diusulkan ini terbukti meningkatkan efisiensi operasi dibandingkan dengan modifikasi algoritma lainnya yang sudah ada. Sebuah metode apriori baru juga telah diajukan dengan memanfaatkan frequent matrix yang diberi nama Frequent Matrix Apriori (FMA) [6].

Metode asosiasi apriori pada riset-riset terkini telah dipakai dalam beberapa kasus, misalnya untuk memberikan rekomendasi produk pada mobile e-commerce [7][8], untuk evaluasi pendidikan[9], memprediksi daerah banjir[10], memahami konektivitas bagianbagian otak[11], memprediksi perilaku penggunaan web pengguna[12], mengetahui asosiasi antara penggunaan obat-obatan dan kejadian buruk dalam Farmakoterapi pada pasien nonsmall cell lung cancer (NSCLC)[13], memprediksi penyakit dengue[14], serta memahami karakteristik Flaviviruses (termasuk Zika virus)[15].

\section{METODE}

Untuk dapat mengetahui pola beli konsumen, langkah pertama yang dilakukan adalah mengambil basis data penjualan dan produk dari aplikasi kasir (Point of Sales) pada swalayan XYZ. Data penjualan menunjukkan produk-produk yang terjual dalam sebuah transaksi yang biasanya tergambar dalam sebuah struk belanja. Produk-produk yang muncul dalam transaksi kemudian dikelompokkan ke dalam 23 kategori seperti yang ditunjukkan pada Tabel 1. Langkah berikutnya, setiap data transaksi akan ditransformasikan ke dalam format file arff untuk dapat diolah dengan perangkat lunak WEKA (Waikato Environment for Knowledge Analysis). Setiap transaksi akan menjadi sebuah baris data yang berisi daftar item / kategori produk dengan 23 kolom yang menunjukkan 23 kategori produk. Jika sebuah produk ada di dalam transaksi, maka akan diberikan label "t" (true), jika tidak, maka diberikan label "?". Contoh data transaksi dalam format file arff ditunjukkan pada gambar 2. Data dalam format arff ini berikutnya akan diproses dengan algoritma asosiasi apriori dengan perangkat lunak WEKA. Untuk setiap association rules yang ditemukan, akan dievaluasi nilai support, confidence, dan lift-nya. Hasil dari proses ini berupa aturan asosiasi yang menunjukkan tren pola beli konsumen di swalayan XYZ. Berdasarkan aturan asosiasi yang ditemukan, maka dibuatlah rekomendasi penempatan produk untuk meningkatkan penjualan.

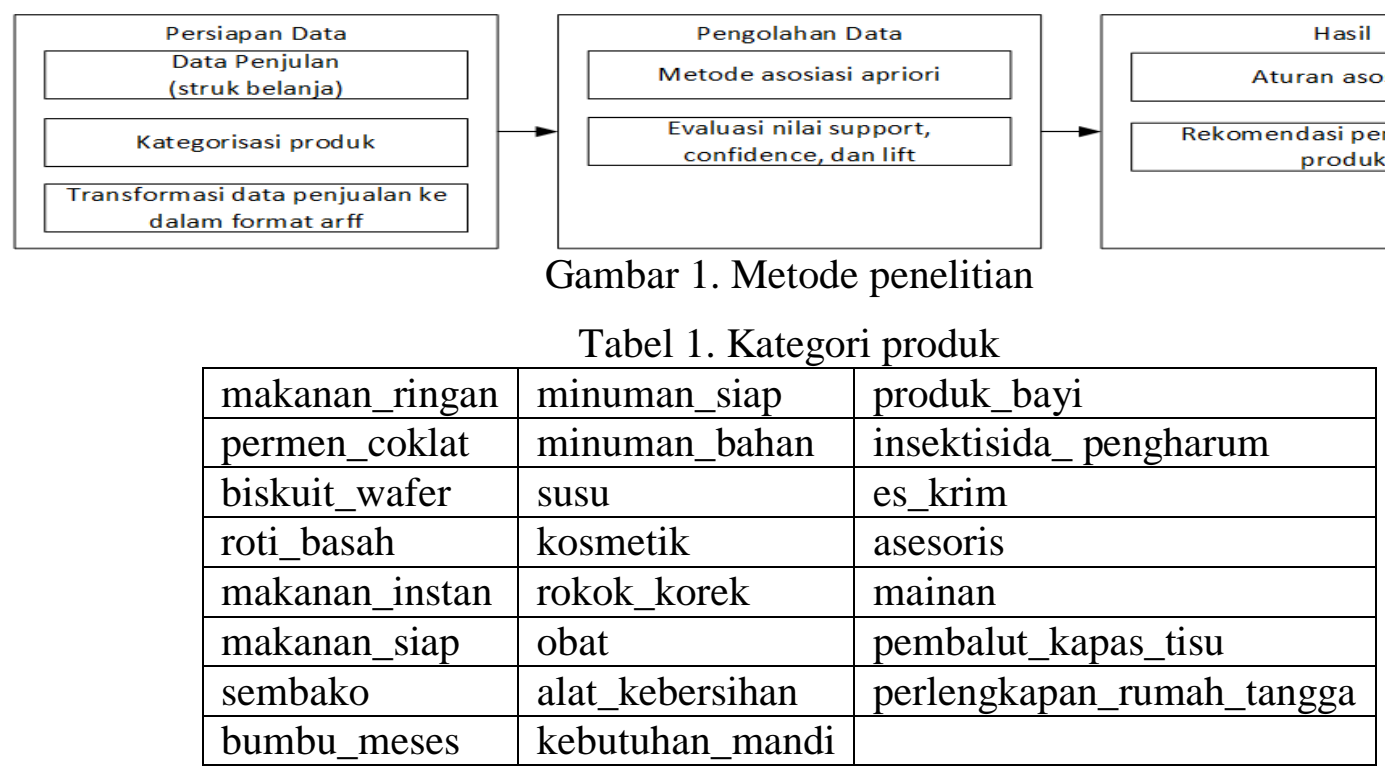




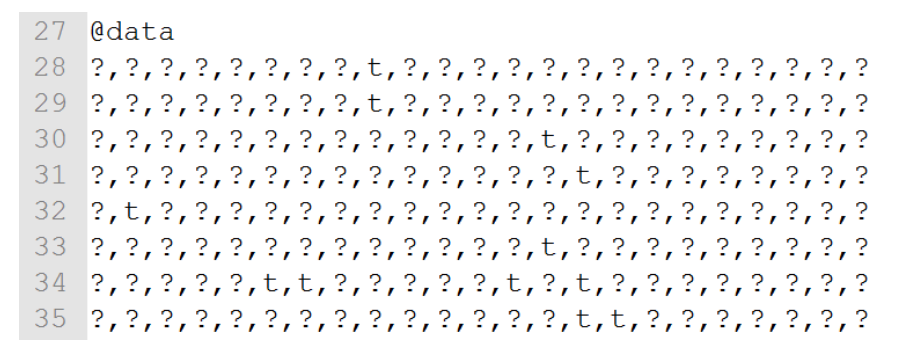

Gambar 2. Contoh data transaksi dalam format arff

\section{HASIL DAN PEMBAHASAN}

Penelitian ini menggunakan 12.760 data transaksi pada bulan April dan Mei 2015. Hasil analisis data transaksi menggunakan metode asosiasi apriori dengan iterasi sebanyak 25 kali (delta $=0,04)$, minimum confidence $=0,2$ dan minimum support $=0,02$ ditunjukkan pada Tabel 2. Beberapa contoh tren asosiasi barang yang muncul dengan support dan confidence yang tinggi antara lain adalah:

a. Jika konsumen membeli biskuit / wafer dan minuman siap, maka dalam 55\% persen kasus mereka juga akan membeli makanan ringan.

b. Jika konsumen membeli peralatan kebersihan, maka dalam 38\% kasus mereka juga akan membeli kebutuhan mandi.

c. Jika konsumen membeli bumbu / meses, maka dalam 36\% kasus mereka juga akan membeli sembako.

d. Jika konsumen membeli kosmetik, maka dalam 35\% kasus mereka juga akan membeli kebutuhan mandi.

Pola (a) dapat dipahami bahwa memang banyak konsumen yang datang ke swalayan untuk membeli camilan sekaligus dengan minuman. Konsumen yang melakukan hal ini biasanya mereka yang sedang dalam perjalanan dan mampir ke swalayan untuk membeli camilan dan minuman siap. Walaupun tidak menutup kemungkinan bahwa konsumen seperti anak-anak dan warga sekitar juga akan melakukan hal yang sama. Pola (b) menunjukkan pola pembelian konsumen yang sudah berkeluarga seperti seorang ibu ataupun ayah yang berbelanja secara rutin untuk kebutuhan rumah tangga yaitu perlatan kebersihan dan kebutuhan mandi. Pola (c) juga menunjukkan pola beli konsumen rumah tangga (utamanya ibu-ibu) yang membeli bumbu bersamaan dengan sembako. Sedangkan pola (d) merupakan pola keterkaitan antara pembelian kosmetik dan kebutuhan mandi yang sangat mungkin terjadi pada konsumen segala umur dan gender, meski lebih cenderung ke konsumen perempuan.

Contoh penghitungan nilai support dan confidence untuk pola (b) adalah sebagai berikut:

Support, $S\left(\right.$ alat $_{\text {kebersihan }} \rightarrow$ kebutuhan $\left._{\text {mandi }}\right)=\frac{\sigma(\text { alat_kebersihan } \cup \text { kebutuhan_mandi })}{N}$

$S($ alat_kebersihan $\rightarrow$ kebutuhan_mandi $)=\frac{(1415 \cup 535)}{12760}=\frac{537}{12760}=0,042$

Confidence, $C($ alat_kebersihan $\rightarrow$ kebutuhan_mandi $)=\frac{\sigma(\text { alat_kebersihan } \cup \text { kebutuhan_mandi })}{\sigma(\text { alat_kebersihan })}$

$C($ alat_kebersihan $\rightarrow$ kebutuhan_mandi $)=\frac{(1415 \cup 537)}{(1415)}=\frac{537}{1415}=0,38$

Nilai support sebesar 0,042 berarti bahwa terdapat 4,2\% data transaksi yang mendukung pola beli "alat_kebersihan $\rightarrow$ kebutuhan_mandi" dari keseluruhan data transaksi yang ada, atau sebanyak 537 kasus dari 12760 transaksi. Sementara nilai confidence sebesar 
0,38 berarti bahwa terdapat $38 \%$ persen transaksi (537 transaksi dari 1415 transaksi) di mana konsumen yang membeli alat kebersihan juga membeli kebutuhan mandi (sementara $62 \%$ konsumen yang membeli alat kebersihan tidak disertai dengan membeli produk kebutuhan mandi).

Tabel 2. Temuan association rules

\begin{tabular}{|c|c|c|c|c|}
\hline Antecedent & $\begin{array}{c}\text { Antecedent } \\
\text { Support } \\
(* 1 / 12760)\end{array}$ & Consequent & $\begin{array}{c}\text { Consequent } \\
\text { Support } \\
(* 1 / 12760)\end{array}$ & Confidence \\
\hline $\begin{array}{l}\text { biskuit_wafer, } \\
\text { minuman_siap }\end{array}$ & 509 & makan_ringan & 278 & 0,55 \\
\hline $\begin{array}{l}\text { makan_ringan, } \\
\text { biskuit_wafer }\end{array}$ & 614 & minuman_siap & 278 & 0,45 \\
\hline biskuit_wafer & 1388 & makan_ringan & 614 & 0,44 \\
\hline alat_kebersihan & 1415 & kebutuhan_mandi & 537 & 0,38 \\
\hline makan_ringan & 2525 & minuman_siap & 953 & 0,38 \\
\hline biskuit_wafer & 1388 & minuman_siap & 509 & 0,37 \\
\hline bumbu_meses & 780 & sembako & 279 & 0,36 \\
\hline kosmetik & 1274 & kebutuhan_mandi & 450 & 0,35 \\
\hline minuman_bahan & 1336 & sembako & 469 & 0,35 \\
\hline permen_coklat & 1471 & minuman_siap & 512 & 0,35 \\
\hline roti & 1094 & makan_ringan & 377 & 0,34 \\
\hline kebutuhan_mandi & 1618 & alat_kebersihan & 537 & 0,33 \\
\hline roti & 1094 & minuman_siap & 362 & 0,33 \\
\hline makan_instan & 1610 & sembako & 525 & 0,33 \\
\hline permen_coklat & 1471 & makan_ringan & 469 & 0,32 \\
\hline makan_instan & 1610 & makan_ringan & 475 & 0,3 \\
\hline pembalut_kapas_tisu & 1013 & kebutuhan_mandi & 297 & 0,29 \\
\hline $\begin{array}{l}\text { makan_ringan, } \\
\text { minuman_siap }\end{array}$ & 953 & biskuit_wafer & 278 & 0,29 \\
\hline alat_kebersihan & 1415 & sembako & 406 & 0,29 \\
\hline kebutuhan_mandi & 1618 & kosmetik & 450 & 0,28 \\
\hline minuman_siap & 3430 & makan_ringan & 953 & 0,28 \\
\hline minuman_bahan & 1336 & makan_ringan & 371 & 0,28 \\
\hline makan_instan & 1610 & minuman_siap & 422 & 0,26 \\
\hline pembalut_kapas_tisu & 1013 & alat_kebersihan & 259 & 0,26 \\
\hline minuman_bahan & 1336 & makan_instan & 335 & 0,25 \\
\hline sembako & 2122 & makan_instan & 525 & 0,25 \\
\hline minuman_bahan & 1336 & minuman_siap & 327 & 0,24 \\
\hline makan_ringan & 2525 & biskuit_wafer & 614 & 0,24 \\
\hline minuman_bahan & 1336 & kebutuhan_mandi & 323 & 0,24 \\
\hline kebutuhan_mandi & 1618 & makan_ringan & 391 & 0,24 \\
\hline alat_kebersihan & 1415 & makan_ringan & 341 & 0,24 \\
\hline kebutuhan_mandi & 1618 & sembako & 380 & 0,23 \\
\hline alat_kebersihan & 1415 & minuman_siap & 319 & 0,23 \\
\hline kebutuhan_mandi & 1618 & minuman_siap & 359 & 0,22 \\
\hline sembako & 2122 & minuman_bahan & 469 & 0,22 \\
\hline makan_instan & 1610 & kebutuhan_mandi & 354 & 0,22 \\
\hline kebutuhan_mandi & 1618 & makan_instan & 354 & 0,22 \\
\hline kosmetik & 1274 & alat_kebersihan & 278 & 0,22 \\
\hline
\end{tabular}




\begin{tabular}{|l|c|l|c|c|} 
alat_kebersihan & 1415 & makan_instan & 300 & 0,21 \\
\hline minuman_bahan & 1336 & alat_kebersihan & 281 & 0,21 \\
\hline biskuit_wafer & 1388 & permen_coklat & 291 & 0,21 \\
\hline makan_instan & 1610 & minuman_bahan & 335 & 0,21 \\
\hline es_krim & 1377 & minuman_siap & 276 & 0,2 \\
\hline biskuit_wafer & 1388 & $\begin{array}{l}\text { makan_ringan, } \\
\text { minuman_siap }\end{array}$ & 278 & 0,2 \\
\hline
\end{tabular}

Untuk membantu mengelompokkan kategori barang yang berkaitan, kami menjalankan analisis sekali lagi dengan me-rangking tingkat keterhubungan antar kategori melalui besaran lift. Lift didefinisikan sebagai lift $=\operatorname{support}(\mathrm{X}, \mathrm{Y}) / \operatorname{support}(\mathrm{X}) \cdot \operatorname{support}(\mathrm{Y})$. Jika nilai lift $=1$, maka $\mathrm{X}$ dan $\mathrm{Y}$ saling berdiri sendiri. Nilai lift yang tinggi menunjukkan adanya keterkaitan khusus antara $\mathrm{X}$ dan $\mathrm{Y}$ yang bukan sekedar kebetulan. Hasil analisis lift untuk data transaksi swalayan XYZ dengan iterasi sebanyak 25 kali $($ delta $=0,04)$, minimum lift $=1,1$ dan minimum support = 0,02 ditunjukkan pada Tabel 3 .

Hasil analisis lift cenderung mengkonfirmasi ulang bahwa memang ada keterkaitan yang kuat antara barang-barang dalam hasil temuan pola asosiasi pada tabel 2. Setiap pasangan barang yang terkait akan muncul sebanyak dua kali dalam tabel 3 karena lift memang mengukur keterkaitan antar barang baik dari X ke Y maupun dari Y ke X yang akan memberikan nilai lift yang sama, tetapi nilai confidence yang berbeda. Nilai confidence yang berbeda disebabkan oleh nilai support kasus X dan Y yang berbeda ketika berada pada posisi antecedent dan consequent.

Tabel 3. Temuan analisis lift

\begin{tabular}{|c|l|l|c|c|}
\hline No & \multicolumn{1}{|c|}{ Antecedent } & \multicolumn{1}{c|}{ Consequent } & Confidence \\
\hline 1 & kebutuhan_mandi & alat_kebersihan & 2,99 & 0,33 \\
\hline 2 & alat_kebersihan & kebutuhan_mandi & 2,99 & 0,38 \\
\hline 3 & kebutuhan_mandi & kosmetik & 2,79 & 0,28 \\
\hline 4 & kosmetik & kebutuhan_mandi & 2,79 & 0,35 \\
\hline 5 & makan_ringan & biskuit_wafer, minuman_siap & 2,76 & 0,11 \\
\hline 6 & biskuit_wafer, minuman_siap & makan_ringan & 2,76 & 0,55 \\
\hline 7 & biskuit_wafer & makan_ringan,minuman_siap & 2,68 & 0,20 \\
\hline 8 & makan_ringan, minuman_siap & biskuit_wafer & 2,68 & 0,29 \\
\hline 9 & kebutuhan_mandi & pembalut_kapas_tisu & 2,31 & 0,18 \\
\hline 10 & alat_kebersihan & pembalut_kapas_tisu & 2,31 & 0,18 \\
\hline 11 & pembalut_kapas_tisu & kebutuhan_mandi & 2,31 & 0,29 \\
\hline 12 & pembalut_kapas_tisu & alat_kebersihan & 2,31 & 0,26 \\
\hline 13 & makan_ringan & biskuit_wafer & 2,24 & 0,24 \\
\hline 14 & biskuit_wafer & makan_ringan & 2,24 & 0,44 \\
\hline 15 & sembako & bumbu_meses & 2,15 & 0,13 \\
\hline 16 & bumbu_meses & sembako & 2,15 & 0,36 \\
\hline 17 & sembako & minuman_bahan & 2,11 & 0,22 \\
\hline 18 & minuman_bahan & sembako & 2,11 & 0,35 \\
\hline 19 & makan_instan & minuman_bahan & 1,99 & 0,21 \\
\hline 20 & minuman_bahan & makan_instan & 1,99 & 0,25 \\
\hline 21 & alat_kebersihan & kosmetik & 1,97 & 0,20 \\
\hline 22 & kosmetik & alat_kebersihan & 1,97 & 0,22 \\
\hline 23 & sembako & makan_instan & 1,96 & 0,25 \\
\hline 24 & makan_instan & sembako & 1,96 & 0,33 \\
\hline 25 & kebutuhan_mandi & minuman_bahan & 1,91 & 0,20 \\
\hline & & &
\end{tabular}




\begin{tabular}{|l|l|l|c|c|}
\hline 26 & minuman_bahan & kebutuhan_mandi & 1,91 & 0,24 \\
\hline 27 & alat_kebersihan & minuman_bahan & 1,90 & 0,20 \\
\hline 28 & minuman_bahan & alat_kebersihan & 1,90 & 0,21 \\
\hline 29 & permen_coklat & biskuit_wafer & 1,82 & 0,20 \\
\hline 30 & biskuit_wafer & permen_coklat & 1,82 & 0,21 \\
\hline 31 & makan_ringan & Roti & 1,74 & 0,15 \\
\hline 32 & roti & makan_ringan & 1,74 & 0,34 \\
\hline 33 & sembako & alat_kebersihan & 1,73 & 0,19 \\
\hline 34 & kebutuhan_mandi & makan_instan & 1,73 & 0,22 \\
\hline 35 & makan_instan & kebutuhan_mandi & 1,73 & 0,22 \\
\hline 36 & alat_kebersihan & sembako & 1,73 & 0,29 \\
\hline 37 & minuman_siap & makan_ringan,biskuit_wafer & 1,68 & 0,08 \\
\hline 38 & makan_instan & alat_kebersihan & 1,68 & 0,19 \\
\hline 39 & alat_kebersihan & makan_instan & 1,68 & 0,21 \\
\hline 40 & makan_ringan, biskuit_wafer & minuman_siap & 1,68 & 0,45 \\
\hline 41 & makan_ringan & permen_coklat & 1,61 & 0,19 \\
\hline 42 & permen_coklat & makan_ringan & 1,61 & 0,32 \\
\hline 43 & makan_instan & biskuit_wafer & 1,58 & 0,17 \\
\hline 44 & biskuit_wafer & makan_instan & 1,58 & 0,20 \\
\hline 45 & makan_ringan & makan_instan & 1,49 & 0,19 \\
\hline 46 & makan_instan & makan_ringan & 1,49 & 0,30 \\
\hline 47 & sembako & kebutuhan_mandi & 1,41 & 0,18 \\
\hline 48 & kebutuhan_mandi & sembako & 1,41 & 0,23 \\
\hline 49 & minuman_siap & makan_ringan & 1,40 & 0,28 \\
\hline 50 & makan_ringan & minuman_siap & 1,40 & 0,38 \\
\hline 51 & makan_ringan & minuman_bahan & 1,40 & 0,15 \\
\hline 52 & minuman_bahan & makan_ringan & 1,40 & 0,28 \\
\hline 53 & minuman_siap & biskuit_wafer & 1,36 & 0,15 \\
\hline 54 & biskuit_wafer & minuman_siap & 1,36 & 0,37 \\
\hline 55 & minuman_siap & permen_coklat & 1,29 & 0,15 \\
\hline 56 & permen_coklat & minuman_siap & 1,29 & 0,35 \\
\hline 57 & minuman_siap & Roti & 1,23 & 0,11 \\
\hline 58 & roti & minuman_siap & 1,23 & 0,33 \\
\hline 59 & makan_ringan & kebutuhan_mandi & 1,22 & 0,15 \\
\hline 60 & makan_ringan & alat_kebersihan & 0,22 & 0,24 \\
\hline 61 & kebutuhan_mandi & 1,22 & 0,14 \\
\hline 62 & alat_kebersihan & makan_ringan & & 0,24 \\
\hline & Rangan & & \\
\hline
\end{tabular}

Berdasarkan temuan rules dan ranking lift tersebut, kami memberikan saran layout baru untuk peletakan produk dengan tujuan memaksimalkan exposure barang terkait saat konsumen berbelanja suatu barang. Layout disusun dengan cara menata barang-barang yang berkaitan erat secara berdekatan. Dengan penataan yang seperti ini, konsumen yang terlah terbiasa melaukan pembelian barang secara berpasangan akan menjadi dimudahkan karena dekat untuk menjangkau barang kebutuhan berikutnya, sementara untuk konsumen yang terbiasa untuk membeli salah satu dari pasangan barang akan terdorong untuk mebeli barang pasangannya. Perbandingan antara layout lama dan layout baru ditunjukkan pada Gambar 3. 


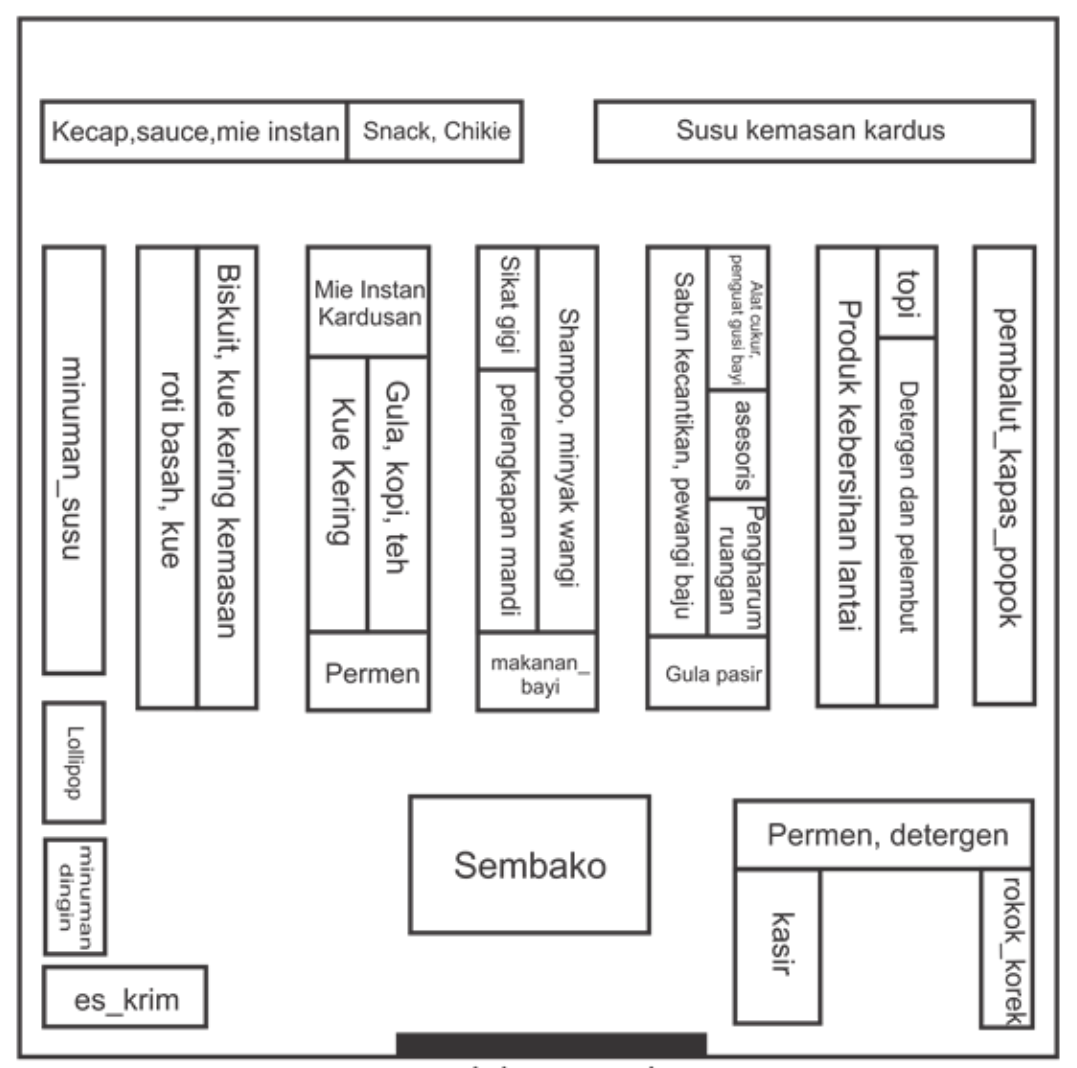

Jalan masuk

A

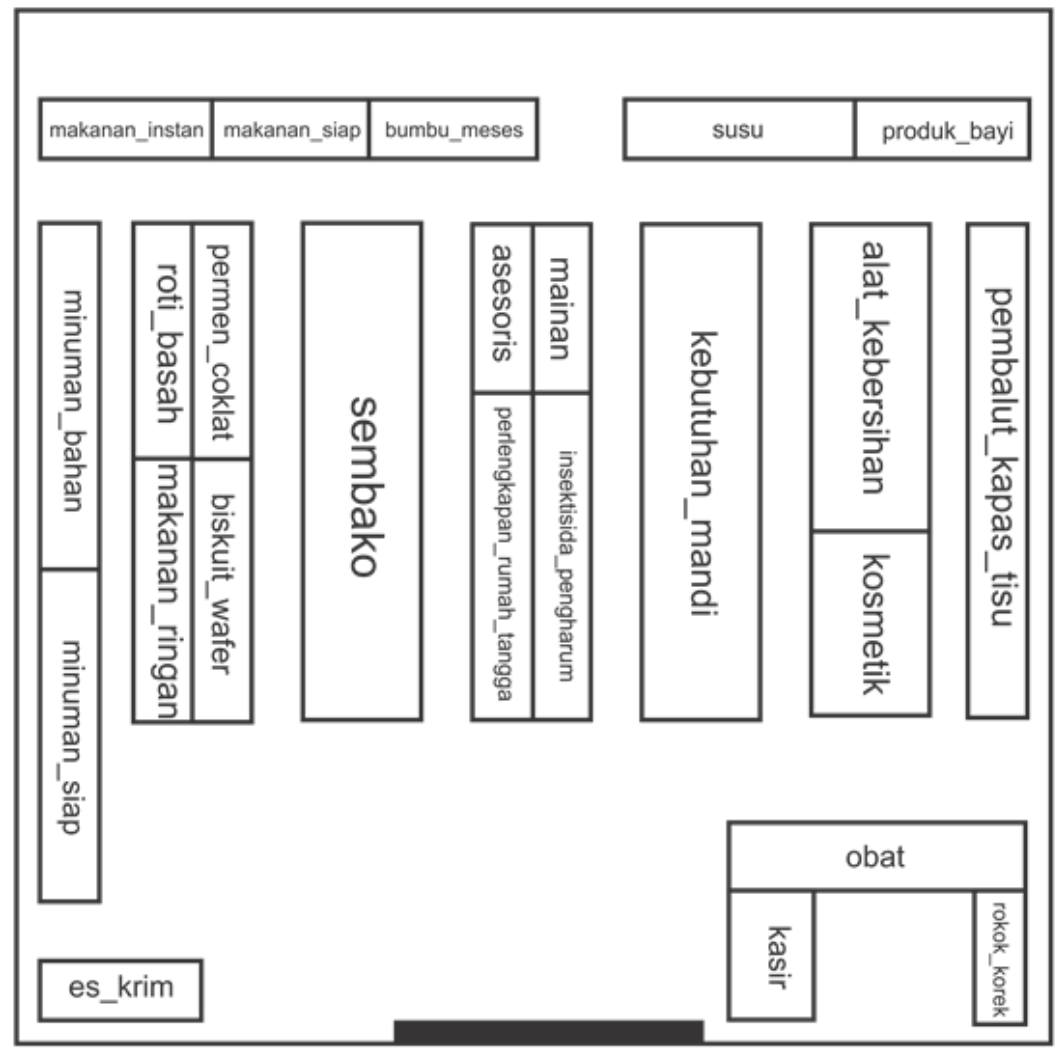

Jalan masuk

$\mathrm{B}$

Gambar 3. Denah penempatan produk sebelum (A) dan sesudah (B). 


\section{KESIMPULAN}

Memahami konsumen sangat diperlukan dalam usaha retail. Metode asosiasi dalam Machine Learning dapat kita manfaatkan untuk menemukan tren pola perilaku beli konsumen yang menunjukkan keterkaitan antar produk. Dengan menganalisis data historis dari perilaku berbelanja konsumen, penelitian ini menemukan tren asosiasi antar kategori barang yang dibeli. Berdasarkan tren asosiasi ini, dibuatlah rekomendasi layout peletakan produk untuk memaksimalkan exposure barang terkait saat konsumen berbelanja suatu barang sehingga diharapkan akan terjadi peningkatan penjualan.

\section{DAFTAR PUSTAKA}

[1] I. Surjandari and A. Seruni, "Design of product placement layout in retail shop using market basket analysis," Makara J. Technol., vol. 9, no. 2, pp. 43-47, 2010.

[2] D. L. Olson and D. Delen, Advanced data mining techniques. Springer Science \& Business Media, 2008.

[3] P.-N. Tan, M. Steinbach, and V. Kumar, "Association analysis: basic concepts and algorithms," in Introduction to Data mining, vol. 321321367, Addison-Wesley Boston, MA, 2005.

[4] R. Agrawal, T. Imieliński, and A. Swami, "Mining association rules between sets of items in large databases," in Acm sigmod record, 1993, vol. 22, no. 2, pp. 207-216.

[5] X. Yuan, "An improved Apriori algorithm for mining association rules," in AIP conference proceedings, 2017, vol. 1820, no. 1, p. 80005.

[6] K. Niu, H. Jiao, Z. Gao, C. Chen, and H. Zhang, "A developed apriori algorithm based on frequent matrix," in ACM International Conference Proceeding Series, 2017, pp. $55-58$.

[7] Y. Guo, M. Wang, and X. Li, "Application of an improved Apriori algorithm in a mobile e-commerce recommendation system," Ind. Manag. Data Syst., vol. 117, no. 2, pp. 287-303, 2017.

[8] S. Bandyopadhyay, S. S. Thakur, and J. K. Mandal, "Product recommendation for Ecommerce data using association rule and apriori algorithm," in Advances in Intelligent Systems and Computing, 2019, vol. 749, pp. 585-593.

[9] C. L. Mao, S. L. Zou, and J. H. Yin, "Educational evaluation based on Apriori-Gen algorithm," Eurasia J. Math. Sci. Technol. Educ., vol. 13, no. 10, pp. 6555-6564, 2017.

[10] N. A. Harun, M. Makhtar, A. A. Aziz, Z. A. Zakaria, F. S. Abdullah, and J. A. Jusoh, "The application of apriori algorithm in predicting flood areas," Int. J. Adv. Sci. Eng. Inf. Technol., vol. 7, no. 3, pp. 763-769, 2017.

[11] Z. Niu, Y. Nie, Q. Zhou, L. Zhu, and J. Wei, "A brain-region-based meta-analysis method utilizing the Apriori algorithm," BMC Neurosci., vol. 17, no. 1, p. 23, 2016.

[12] J. Yang, H. Huang, and X. Jin, "Mining web access sequence with improved apriori algorithm," in 2017 IEEE International Conference on Computational Science and Engineering (CSE) and IEEE International Conference on Embedded and Ubiquitous Computing (EUC), 2017, vol. 1, pp. 780-784.

[13] W. Chen, J. Yang, H.-L. Wang, Y.-F. Shi, H. Tang, and G.-H. Li, "Discovering Associations of Adverse Events with Pharmacotherapy in Patients with Non-Small Cell Lung Cancer Using Modified Apriori Algorithm,” Biomed Res. Int., vol. 2018, 2018.

[14] I. Jahangir, A. Hannan, S. Javed, and others, "Prediction of Dengue Disease through Data Mining by using Modified Apriori Algorithm," in Proceedings of the 4th ACM International Conference of Computing for Engineering and Sciences, 2018, p. 5. 
[15] Y. Yang, B. Gu, and T. Yoon, "Deeper understanding of Flaviviruses including Zika virus by using Apriori Algorithm and Decision Tree," in MATEC Web of Conferences, 2016, vol. 69, p. 1005. 